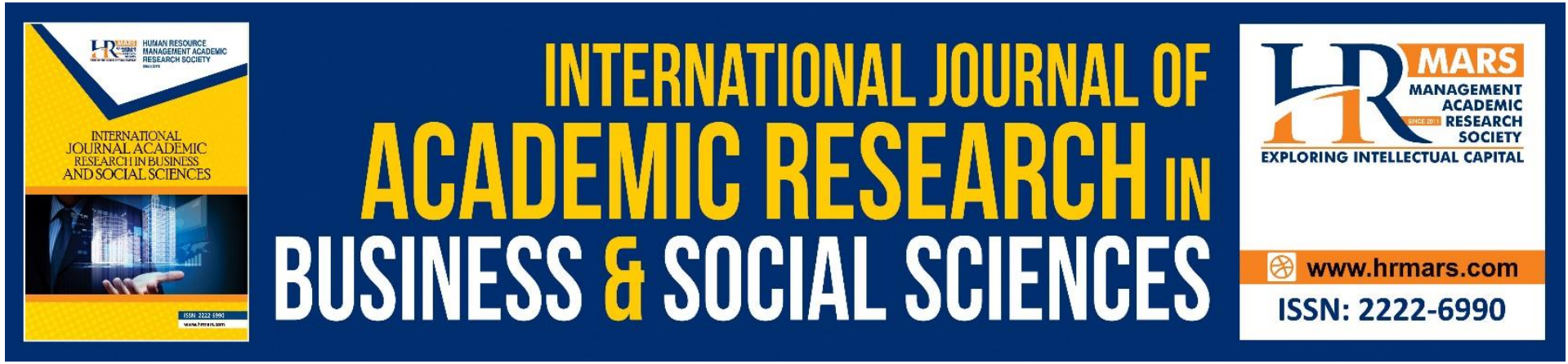

\title{
Regenerate Post COVID-19 Tourism with Smart Tourism Application (Moh Poie Rembau - Let's Go to Rembau) as the Next Cultural Tourism \& Travel Destination in Malaysia
}

Dzaa Imma Abdul Latiff, Muhamed Shafiq Mohamed Ayub, Suhaila Kamal \& Wan Anis Aqilah Megat Zambri

To Link this Article: http://dx.doi.org/10.6007/IJARBSS/v11-i9/10704

DOI:10.6007/IJARBSS/v11-i9/10704

Received: 16 July 2021, Revised: 18 August 2021, Accepted: 30 August 2021

Published Online: 14 September 2021

In-Text Citation: (Latiff et al., 2021)

To Cite this Article: Latiff, D. I. A., Ayub, M. S. M., Kamal, S., \& Zambri, W. A. A. M. (2021). Regenerate Post COVID-19 Tourism with Smart Tourism Application (Moh Poie Rembau - Let's Go to Rembau) as the Next Cultural Tourism \& Travel Destination in Malaysia. International Journal of Academic Research in Business and Social Sciences, 11(9), 592-604.

\section{Copyright: @ 2021 The Author(s)}

Published by Human Resource Management Academic Research Society (www.hrmars.com)

This article is published under the Creative Commons Attribution (CC BY 4.0) license. Anyone may reproduce, distribute, translate and create derivative works of this article (for both commercial and non-commercial purposes), subject to full attribution to the original publication and authors. The full terms of this license may be seen at: http://creativecommons.org/licences/by/4.0/legalcode

Vol. 11, No. 9, 2021, Pg. 592 - 604

Full Terms \& Conditions of access and use can be found at http://hrmars.com/index.php/pages/detail/publication-ethics 


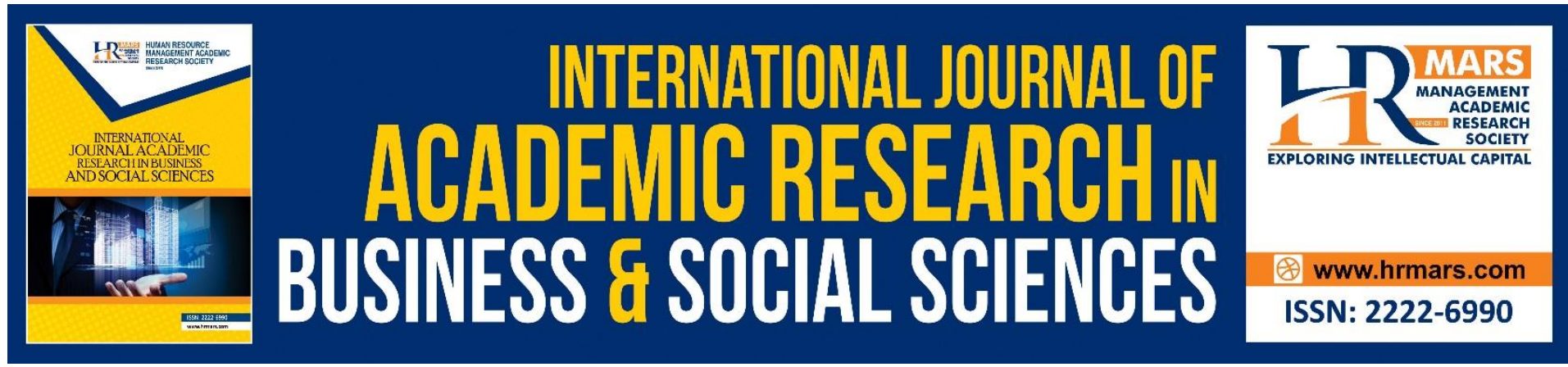

\title{
Regenerate Post COVID-19 Tourism with Smart Tourism Application (Moh Poie Rembau - Let's Go to Rembau) as the Next Cultural Tourism \& Travel Destination in Malaysia
}

\author{
Dzaa Imma Abdul Latiff, Muhamed Shafiq Mohamed Ayub, \\ Suhaila Kamal \& Wan Anis Aqilah Megat Zambri \\ Universiti Teknologi MARA, Negeri Sembilan, Kampus Rembau, Malaysia \\ Email: dzaa17@uitm.edu.my
}

\begin{abstract}
The outlook for the tourism sector in Malaysia remains highly uncertain. The coronavirus (COVID-19) pandemic continues to hit hard in which by 2022 the domestic tourism is expected to decrease by around $80 \%$. To regenerate our local tourism income, a smart tourism application known as 'Moh Poie Rembau' or Let's Go to Rembau has been developed to strengthen the domestic tourism industry. Rembau, Negeri Sembilan is a tourist destination with a huge tourism potential that includes rich culture, heritage, buildings, and gastronomy. However, the culture of Rembau has different attractions for tourists due to lack of and disorganized information on tourism developments, supporting facilities, tourism objects, and visitor information about the locals. Many undiscovered places are worth visiting, but many are unaware of their existence due to the lack of tourism information. This research aims to identify the feedback on the importance of smart tourism application use on smartphones. This application is designed to attract travelers to choose Rembau as their next destination plan. A cross-sectional survey of the 14-item instrument was adapted and distributed online to a total of 150 smartphone users in Klang Valley during the first week of March 2021. Most of the users have high and positive responses towards this product. The findings supported the idea that smart tourism applications can give impact users' intention to use. The results also improved our knowledge and understanding that this application can be a part of the tourism approach in promoting Rembau as one of the tourism attractions. The application will provide information about tourist attractions, hotels, restaurants, shopping attractions, and other facilities with just one click away. This study is beneficial and significant for the researchers, tourism agencies, media practitioners, and the public to maintain digital technology and travel in line.
\end{abstract}

Keywords: Application, Tourism, Travelling, Smartphones, Rembau 


\section{Introduction}

The COVID-19 pandemic gave a huge impact on the tourism industry due to the travel restrictions it created. The tourism industry has been heavily affected by the spread of the coronavirus, as many countries have implemented travel bans to stop it from spreading. As a result of movement control orders, exit and entry into the country either in full (e.g. Australia, New Zealand, Philippines, Saudi Arabia) or in part (e.g. South Korea, United States, Canada) have greatly affected most economic sectors primarily the tourism sector. As of March 2020, Covid-19 has caused a total loss of almost RM10 billion to the country. Meanwhile, the United Nations World Tourism Organization estimates that global growth is likely to increase by 58\% to $78 \%$ by 2020 , resulting in consumer losses of US $\$ 0.9-1.2$ trillion. In general, the tourism sector in Malaysia has gained worldwide recognition from various quarters. In the health tourism industry, Malaysia emerged as the No.1 World's Best Healthcare in 2019 and Four Countries with the Best Healthcare in the World in 2017 by International Living. Data from the Malaysia Healthcare Travel Council (MHTC) shows that in 2019, 3.6\% of the total number of tourists to Malaysia were for health purposes (Kefeli, 2020)

Today, tourism industries are competing in generating greater values for customers. Many research have shown that visitors or tourists are becoming more selective in choosing the best destinations. To regenerate our local tourism income, a smart tourism application known as 'Moh Poie Rembau' (MPR) or Let's Go to Rembau has been developed to strengthen the domestic tourism industry. Rembau, a district in Negeri Sembilan, Malaysia, is a tourist destination with a huge tourism potential that includes rich culture, heritage, buildings, and gastronomy. However, the culture of Rembau has different attractions for tourists due to lack of and disorganized information on tourism developments, supporting facilities, tourism objects, and visitor information about the locals. Many undiscovered places are worth visiting, but many are unaware of their existence due to the lack of tourism information. This research aims to identify the feedback on the importance of smart tourism application use on smartphones

\section{Literature Review}

Smart Tourism Application (Moh Poie Rembau - MPR)

Smart Tourism Application or MPR is a prototype application that was developed to serve as a platform to promote Rembau District as a tourist destination, especially to the outsider. Previously, we just rely on search engines such as Google search to explore things that we want. However, by using MPR, users no longer have a hard time checking on the information. This application contains information such as interesting places to visit including historical locations, special food premises, local small industry products, accommodation facilities as well as important information that potential visitors need to know. All this information can be accessed by visitors to help make it easier for them to make a choice and head to the desired destination. This application is also unique and interactive because it has pictures, contact numbers and Global positioning system (GPS) coordinates to make it easier for users when visiting Rembau. Visitors only need to open this application on smartphones and all the info can be obtained in the blink of an eye. Just by clicking on the MPR application on the mobile phone, and all of the information can be explored regardless of time and place. 


\section{Diffusion of Innovation Theory}

Innovation is believed as adetermining factor for organizational achievement or success. The concept of diffusion or the proliferation of new ideas and inventions has always been studied in the early 20th century. Diffusion of innovation theory originally obtained from the field of sociology, which used to explain the procedures and situations of ideas and innovations that are "diffused (spread/dispersed) and are adopted by consumers" (Karakaya et al., 2014 p. 2). Roger (2003, p.12) claimed that innovation refers to "an idea, practice, or object that is perceived as new". Innovation may consist of anything that begins from a new form of knowledge to policy, processes, emerging media platforms, and more. Users are more likely to apply or adopt a technology when it is seen as having some relative advantage over an existing practice, compatible with current values and needs, less complexity, testable before use, and has observable effects and results (Scott \& McGuire, 2017). As shown in figure 1, the dependent variable (intention to use) is influenced directly by the independent variables which are represented by a) relative advantage, b) ease of use (complexity), c) compatibility and d) trialability. In this study, the "observation" has been excluded because MPR is a prototype application and has never been exposed to the public except for the respondents during the trial period.

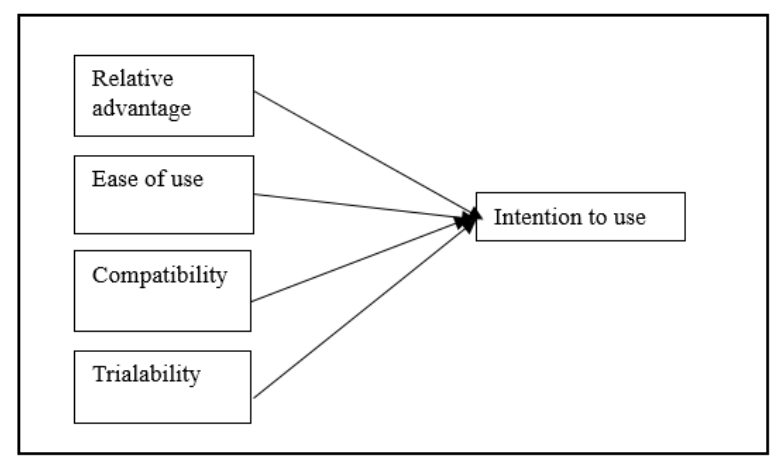

Figure 1: Research Framework

\section{Relative Advantage}

Relative advantage can be defined as "the degree to which an innovation is perceived as being better than the idea it supersedes" (Rogers, 2003, p. 212). Relative advantage is mostly related to politics, economics, convenience, social, and satisfaction. It might seem like relative advantage alone should be enough to persuade a person to adopt an innovation. The higher audience perceives relative advantage, the higher people adopt. Certainly, the relative advantage is a key indicator of adoption. Polites and Karahanna (2012) mentioned in their study that relative advantage was positively associated with users' intention to use a new system. Meanwhile, Gu et. al. (2019), proved that relative advantage for mobile tourism shopping was significant. MPR offers information in just one click away. Information of beautiful places which include accommodation, GPS, contact number and reviews or feedback from the previous travelers will give benefits to tourist to decide. Therefore, the relative advantage of MPR in the current study can be a significant factor for intention to use.

\section{Ease of use}

Perceived ease of use is defined as "the degree to which an individual believes that using a particular system would be free of physical and mental efforts" (Davis, 1989, p. 323). Ease of use in the Technology Acceptance Model and complexity in Diffusion of Innovation theory investigates the same perception but with opposite direction (negatively correlates). As 
mentioned in the theoretical framework, ease of use will be used, in order to have the same effect direction. Perceived ease of use is also considered to be an important antecedent to an individual's intention to adopt new technology. Previous studies have found positive and significant relationships such as mobile shopping in Malaysia (Wong et. al., 2015; Ghazali et. al., 2018) and mobile tourism shopping as compared to traditional shopping in Pakistan (Gu et al., 2019). MPR is a user-friendly application in which users just need to explore the features that are available. It does not require huge internet data usage and storage for smartphone uses. Therefore, the ease of use of MPR can be a significant indicator of intention to use MPR.

\section{Compatibility}

Compatibility is defined as "the degree to which the adoption of a technology is compatible with existing values, past experiences, and needs of potential adopters" (Rogers, 2003, p. 15). The basic idea behind compatibility is when an innovation that is more compatible becomes less uncertain to a potential adopter (Rogers, 2003). MRP is said to be compatible with the need for mobility especially for the audience with a busy lifestyle. A study on the uber mobile application by Min et al. (2019) showed that compatibility has a positive and significant relationship towards intention to use. Another study by Latiff et al. (2017) on students' intention to adopt Internet TV and streaming news found that compatibility showed a positive and significant effects. The studies showed that users will likely adopt if it is compatible with extremely held cultural standards and compatible with previous ideas. MPR can be used on Android and iOS operating systems. Thus, it is compatible with users' work style and daily routine.

Trialability

Trialability is define as the ease of investigating an innovation. New technology can be tested by potential audiences which are usually adopted more rapidly compared to those technologies that are not offered on any trial basis. Rogers (2003) claimed that personal testing of an innovation (a product or a service) has been seen as a way for users or individuals to understand how the innovation works and dismiss uncertainties in the innovation. Trialability becomes an important attribute for innovation because it may reduce users' uncertainties on new or unfamiliar ideas, technologies, or products. A study by Lee et al. (2011) found that trialability is an important predictor influencing people to adopt IPTV. Therefore, the high trialability of Internet TV especially on a trial basis influences the users to adopt this smart application. In addition, trialability is also influenced by the audience's cultural values or tasks where others might be experiencing or observing the trials. Therefore, trialability is an important variable that can clarify the MPR adoption rate at the early phase of its product launching and promotions.

Thus, the researchers would like to investigate the relationship between innovation attributes of MPR (based on Diffusion of Innovation theory) and intention to use as below:

$\mathrm{H}_{1}$ : Relative advantage of using MPR application has a positive and significant effect on intention to use.

$\mathrm{H}_{2}$ : Ease of use of using MPR application has a positive and significant effect on intention to use.

$\mathrm{H}_{3}$ : Compatibility of using MPR application has a positive and significant effect on intention to use. 
$\mathrm{H}_{4}$ : Trialability of using MPR application has a positive and significant effect on intention to use.

\section{Methodology}

\section{Sample and Statistical Procedure}

A cross-sectional, online survey was conducted among smartphone users in Klang Valley during the first week of March 2021. Because this application is just a prototype and still in the process of improvements, thus researchers have used a convenient sampling technique. The MPR application link was attached to the survey to allow the respondents to experience the uniqueness of this application. The data collection process took about two weeks and in total 156 online questionnaires were administrated via Google form. The data were entered and analyzed using SPSS version 24 and six were removed due to invalid responses. The researcher used descriptive analysis to measure the mean and standard deviant. Meanwhile, a multiple regression analysis was also conducted to predict the relationship between innovation attributes of MPR and the user's intention to use.

\section{Instruments and Reliability}

The instruments used were adapted from past research studies on technologies adoption. A 14-item survey instrument was adopted and modified. The questions also included demography items. Respondents were asked about their experiences of using this application such as a) relative advantage b) ease of use c) compatibility and d) trialability of MPR. As mentioned earlier, the variable of observation will not be included because the application is a prototype and has never been used in public before. Thus, it is insignificant to observe this product through friends, family, relatives, or salesperson and advertisement.

Table 1 shows the allocation of instruments, items, reliability test, standardized item loadings, average variance extracted (AVE), composite reliability (CR), and Cronbach alpha (CA). The items used four Likert scales. The instruments were adopted by (Chan-Olmsted \& Chang, 2006; Rogers, 1989) for items such as Relative Advantage and Compatibility; Ease of Use (Davis et al.,1989; Venkatesh et al., 2003), Trialability (Moore \& Benbasat, 1991; Rogers, 1989) and lastly, Intention to use (Venkatesh et. al., 2003; Wu \& Wang, 2005). Before the questionnaires were distributed to the students, researchers will seek help from the experts to confirm that the items of an assessment or instrument are appropriate to the targeted study and objectives. The pre-test had been conducted among 30 Diploma students. The results of the reliability analysis were presented in Table 1 to show that the reliability test is meet after some adjustments or reworded have been made to avoid misunderstanding when the respondents attempted the questionnaire. The factor loading for each item should be 6 or higher and must be positive. It is essential to conduct Average Variance Extracted (AVE) for each construct to measure the validity. Most of the factor loadings were larger than 0.6. The AVEs for all constructs exceed .5 and CRs exceed 6. 
Table 1: Instruments, standardized item loadings, CA values AVE, and CR

\begin{tabular}{|c|c|c|c|c|c|c|c|}
\hline Factor & Instrument & Item & $\begin{array}{l}\text { Item } \\
\text { loadings } \\
\geq .60\end{array}$ & $\begin{array}{l}C A \geq .70 \\
\text { Pilot } \\
\text { Test }\end{array}$ & $\begin{array}{l}\mathrm{CA} \geq .70 \\
\text { Field } \\
\text { Test }\end{array}$ & AVE $\geq .5$ & $\mathrm{CR} \geq .6$ \\
\hline $\begin{array}{l}\text { Relative } \\
\text { Advantage } \\
\text { (RA1, RA2, RA3) }\end{array}$ & $\begin{array}{l}\text { Chan- } \\
\text { Olmsted \& } \\
\text { Chang } \\
(2006) \quad \& \\
\text { Rogers } \\
(1989)\end{array}$ & $\begin{array}{l}\text { RA1 } \\
\text { RA2 } \\
\text { RA3 }\end{array}$ & $\begin{array}{r}.788 \\
.834 \\
.780\end{array}$ & .81 & .84 & .641 & .842 \\
\hline $\begin{array}{l}\text { Ease of use } \\
\text { (EU1, EU2, EU3) }\end{array}$ & $\begin{array}{l}\text { Davis et al. } \\
\text { (1989) \& } \\
\text { Venkatesh } \\
\text { et al., (2003) }\end{array}$ & $\begin{array}{l}\text { EU1 } \\
\text { EU2 } \\
\text { EU3 }\end{array}$ & $\begin{array}{l}.835 \\
.818 \\
.838\end{array}$ & .93 & .92 & .690 & .870 \\
\hline $\begin{array}{l}\text { Compatibility } \\
(\mathrm{CO} 1, \mathrm{CO} 2, \mathrm{CO} 3)\end{array}$ & $\begin{array}{l}\text { Chan- } \\
\text { Olmsted \& } \\
\text { Chang } \\
(2006) \quad \& \\
\text { Rogers } \\
(1989)\end{array}$ & $\begin{array}{l}\mathrm{CO} 1 \\
\mathrm{CO} 2 \\
\mathrm{CO} 3\end{array}$ & $\begin{array}{l}.752 \\
.916 \\
\\
.841\end{array}$ & .91 & .91 & .704 & .877 \\
\hline $\begin{array}{l}\text { Trialability } \\
\text { (TR1, TR2, TR3) }\end{array}$ & $\begin{array}{l}\text { Rogers } \\
\text { (1989) }\end{array}$ & $\begin{array}{l}\text { TR1 } \\
\text { TR2 } \\
\text { TR3 }\end{array}$ & $\begin{array}{l}.836 \\
.844 \\
.802\end{array}$ & .85 & .87 & .685 & .867 \\
\hline $\begin{array}{l}\text { Intention to use } \\
\text { (IN1, IN2) }\end{array}$ & $\begin{array}{l}\text { Venkatesh } \\
\text { et. al., } \\
\text { (2003), and } \\
\text { Wu \& Wang } \\
\text { (2005) }\end{array}$ & $\begin{array}{l}\text { IN1 } \\
\text { IN2 }\end{array}$ & .750 & .72 & .86 & .572 & .727 \\
\hline
\end{tabular}

* Cronbach alpha (CA), average variance extracted (AVE) and composite reliability (CR)

\section{Results}

\section{Profile of the Smart Tourism Application user (MPR)}

Table 2 shows the profile of respondents based on the survey. Most respondents are female (57\%), with most of the age between 16 to 25 years old (34\%). Malays are among the highest rate $(80 \%)$ where most of them are married (53\%). Meanwhile, the highest education levels are among the degree holders (34\%) with students are the highest response rate (31\%). Most of them earned less than RM1,000 (21\%). 
Table 2: Distribution of MPR Application user by profile $(n=150)$

\begin{tabular}{|c|c|c|c|c|c|}
\hline Profile & Frequency & $\begin{array}{l}\text { Percentage } \\
\text { (\%) }\end{array}$ & Profile & Frequency & $\begin{array}{l}\text { Percentage } \\
\text { (\%) }\end{array}$ \\
\hline Gender & & & Status & & \\
\hline Male & 64 & 43 & Single & 66 & 44 \\
\hline \multirow[t]{2}{*}{ Female } & 86 & 57 & Married & 79 & 53 \\
\hline & & & Divorce & 5 & 3 \\
\hline \multicolumn{6}{|l|}{ Age } \\
\hline $16-25$ & 51 & 34 & Education & & \\
\hline $26-35$ & 44 & 29 & $\begin{array}{l}\text { Certificate/PMR } \\
\text { /SPM }\end{array}$ & 49 & 33 \\
\hline $36-45$ & 30 & 20 & Diploma & 35 & 23 \\
\hline $46-55$ & 16 & 11 & Degree & 51 & 34 \\
\hline $55-65$ & 9 & 6 & Master/PhD & 15 & 10 \\
\hline Race & & & Occupation & & \\
\hline Malay & 80 & 53 & Professional & 17 & 11 \\
\hline Chinese & 43 & 29 & Executive & 42 & 28 \\
\hline Indian & 21 & 14 & Non-executive & 30 & 20 \\
\hline \multirow[t]{2}{*}{ Other } & 6 & 4 & Students & 46 & 31 \\
\hline & & & Self employed & 10 & 7 \\
\hline Income & & & Unemployed & 5 & 3 \\
\hline$>1000$ & 46 & 31 & & & \\
\hline $1001-2000$ & 25 & 17 & & & \\
\hline 2001-3000 & 20 & 13 & & & \\
\hline $3001-4000$ & 28 & 19 & & & \\
\hline 4000 above & 31 & 21 & & & \\
\hline
\end{tabular}

Majority of the participants responses agreed that the MPR platform is an effective tool for smart tourism applications. Respondents' feedback on the relative advantage of the MPR application was measured by three questions (RA1-RA3, Table 3). Majority of the participants agreed that the MPR application fits with people's lifestyles (76.7\%), satisfaction, and fulfilled needs better than other search engines. Meanwhile, the ease of use of the MPR application (EU1-EU3) has proven to be user friendly when the majority agreed that this application is easy to use (79\%), easy to learn and easy for respondents to become skilled at using the content of the MPR App. Furthermore, majority of them agreed that the MPR application (CO1-CO2) is compatible with their works (76\%) and lifestyle (73.3\%). Meanwhile, trialability of MPR application (TR1-TR3) confirmed that majority of respondents agreed that they want to be able to try out the MPR application (82.7\%) and on a trial basis (82.7\%). Additionally, items of intention to use MPR application (IN1-IN2) were gauged to check on respondents' attitude to use. They look forward to using this app frequently (74.7\%) and become a heavy user of MPR applications (66\%). 
Table 3: Users attitude on MPR Application, $n=(\%)$

\begin{tabular}{|c|c|c|c|c|c|c|}
\hline Item & SD & $\mathrm{D}$ & $A$ & SA & Mean & SD \\
\hline RA1. MPR App fits with my lifestyle & $\begin{array}{l}4 \\
(2.7)\end{array}$ & $\begin{array}{l}14 \\
(9.3)\end{array}$ & $\begin{array}{l}115 \\
(76.7)\end{array}$ & $\begin{array}{l}17 \\
(11.3)\end{array}$ & 2.97 & .56 \\
\hline $\begin{array}{l}\text { RA2.My satisfaction with MPR App is } \\
\text { higher than the other search engine } \\
\text { that available on Internet. }\end{array}$ & $\begin{array}{l}4 \\
(2.7)\end{array}$ & $\begin{array}{l}19 \\
(12.7)\end{array}$ & $\begin{array}{l}116 \\
(77)\end{array}$ & $\begin{array}{l}11 \\
(7.3)\end{array}$ & 2.89 & .54 \\
\hline $\begin{array}{l}\text { RA3. MPR App fulfills my needs better } \\
\text { than the other search engine that } \\
\text { available on Internet. }\end{array}$ & $\begin{array}{l}3 \\
(2)\end{array}$ & $\begin{array}{l}20 \\
(13.3)\end{array}$ & $\begin{array}{l}119 \\
(79.3)\end{array}$ & $\begin{array}{l}8 \\
(5.3)\end{array}$ & 2.88 & .50 \\
\hline $\begin{array}{l}\text { EU1. Learning to use the content of } \\
\text { MPR App is easy for me }\end{array}$ & $\begin{array}{l}5 \\
(3.3)\end{array}$ & $\begin{array}{l}4 \\
(2.7)\end{array}$ & $\begin{array}{l}119 \\
(79)\end{array}$ & $\begin{array}{l}22 \\
(15)\end{array}$ & 3.01 & .55 \\
\hline $\begin{array}{l}\text { EU2. It is easy to use the content of } \\
\text { MPR App }\end{array}$ & $\begin{array}{l}7 \\
(5)\end{array}$ & $\begin{array}{l}7 \\
(5)\end{array}$ & $\begin{array}{l}118 \\
(79)\end{array}$ & $\begin{array}{l}18 \\
(12)\end{array}$ & 2.98 & .59 \\
\hline $\begin{array}{l}\text { EU3. It is easy for me to become skilled } \\
\text { at using the content of MPR App. }\end{array}$ & $\begin{array}{l}9 \\
(6)\end{array}$ & $\begin{array}{l}5 \\
(3.3)\end{array}$ & $\begin{array}{l}121 \\
(80.7)\end{array}$ & $\begin{array}{l}15 \\
(10)\end{array}$ & 2.95 & .61 \\
\hline $\begin{array}{l}\text { CO1. MPR App would be compatible } \\
\text { with most aspects of my work. }\end{array}$ & $\begin{array}{l}1 \\
(0.7)\end{array}$ & $\begin{array}{l}24 \\
(16)\end{array}$ & $\begin{array}{l}114 \\
(76)\end{array}$ & $\begin{array}{l}11 \\
(7.3)\end{array}$ & 2.90 & .50 \\
\hline CO2. MPR App would fit my work style. & $\begin{array}{l}1 \\
(0.7)\end{array}$ & $\begin{array}{l}26 \\
(17.3)\end{array}$ & $\begin{array}{l}110 \\
(73.3)\end{array}$ & $\begin{array}{l}13 \\
(8.7)\end{array}$ & 2.90 & .53 \\
\hline $\begin{array}{l}\text { CO3. MPR App would fit well with the } \\
\text { way I like to work }\end{array}$ & $\begin{array}{l}1 \\
(0.7)\end{array}$ & $\begin{array}{l}27 \\
(18)\end{array}$ & $\begin{array}{l}110 \\
(73.3)\end{array}$ & $\begin{array}{l}12 \\
(8)\end{array}$ & 2.89 & .52 \\
\hline $\begin{array}{l}\text { TR1. I want to be able to properly try } \\
\text { out MPR App. }\end{array}$ & $\begin{array}{l}2 \\
(1.3)\end{array}$ & $\begin{array}{l}6 \\
(4)\end{array}$ & $\begin{array}{l}124 \\
(82.7)\end{array}$ & $\begin{array}{l}18 \\
(12)\end{array}$ & 3.05 & .46 \\
\hline $\begin{array}{l}\text { TR2. I want to be permitted to use MPR } \\
\text { App, on a trial basis long enough to see } \\
\text { what it can do. }\end{array}$ & $\begin{array}{l}7 \\
(5)\end{array}$ & $\begin{array}{l}3 \\
(2)\end{array}$ & $\begin{array}{l}124 \\
(82.7)\end{array}$ & $\begin{array}{l}16 \\
(10.7)\end{array}$ & 2.97 & .61 \\
\hline $\begin{array}{l}\text { TR3. I want to be able to use MPR App } \\
\text { on a trial basis. }\end{array}$ & $\begin{array}{l}9 \\
(6)\end{array}$ & $\begin{array}{l}9 \\
(6)\end{array}$ & $\begin{array}{l}119 \\
(79.3)\end{array}$ & $\begin{array}{l}13 \\
(8.7)\end{array}$ & 2.91 & .62 \\
\hline IN1. I intend to use MPR App frequently & $\begin{array}{l}1 \\
(0.7)\end{array}$ & $\begin{array}{l}23 \\
(15.3)\end{array}$ & $\begin{array}{l}112 \\
(74.7)\end{array}$ & $\begin{array}{l}14 \\
(9.3)\end{array}$ & 2.93 & .52 \\
\hline $\begin{array}{l}\text { IN2. I intend to be a heavy user of MPR } \\
\text { App system. }\end{array}$ & $\begin{array}{l}3 \\
(2)\end{array}$ & $\begin{array}{l}33 \\
(22)\end{array}$ & $\begin{array}{l}99 \\
(66)\end{array}$ & $\begin{array}{l}15 \\
(10)\end{array}$ & 2.84 & .61 \\
\hline
\end{tabular}

*SD=Strongly Disagree, $D=$ Disagree, $A=$ Agree and $S A=$ Strongly Agree

A multiple regression analysis using the enter method was conducted to examine whether a) relative advantage $b$ ) ease of use $c$ ) compatibility and d) trialability of smart tourism MPR application have a positive and significant effect on the intention to use. Overall, the model was significant, $F(4,145)=45.03, p<0.001$, explaining $47.1 \%\left(R^{2}=.47\right)$ of the variance in the outcome variable. Thus, table 4 shows that all variables of the MPR application reported positive and have a significant effect on the intention to use. Therefore $H_{1}, H_{2}, H_{3}$ and $H_{4}$ is supported. 
Table 4: Results of multiple regression analysis

\begin{tabular}{llllllll}
\hline ariables & \multicolumn{2}{l}{$\begin{array}{l}\text { Unstandardized } \\
\text { Coefficient }\end{array}$} & $\begin{array}{l}\text { Standardized } \\
\text { Coefficient }\end{array}$ & $\mathbf{t}$ & Sig & $\mathbf{R}^{\mathbf{2}}$ & $\boldsymbol{F}$ \\
\hline Constant & $B$ & SE & Beta & & & & \\
Relative Advantage & .42 & .25 & & 1.70 & .09 & .471 & 32.324 \\
Ease of use & .39 & .07 & .38 & 5.29 & $.00^{* *}$ & & \\
Compatibility & .22 & .08 & .22 & 3.22 & $.00^{* *}$ & & \\
Trialability & .41 & .08 & .38 & 5.02 & $.00^{* *}$ & & \\
& .28 & .07 & .31 & 3.91 & $.01^{*}$ & & \\
\hline
\end{tabular}

$* * p>0.001, * p>0.05$

\section{Discussion}

The study shows that overall, the respondents in Klang Valley have good responses towards Smart Tourism Application (MPR) on smartphones. Majority of them cited that this application fits their lifestyle, work style and feel satisfied with the information offered by this application as compared to any other search engine. As indicated in Table 4, the results of the hypotheses show a positive and significant relationship. Hypotheses 1 shows a positive and significant relationship $(\beta=.39, p<.001)$ between the relative advantage of MPR application and intention to use. The results are found significantly aligned with the previous study by Bae and Chang (2012) which found that relative advantage is the strongest predictor of purchase intention of smart TV. This indicates that as satisfaction from smart tourism MPR application is higher and fit their lifestyle, thus, increased users' intention to use. The higher audience perceives relative advantage, the higher people adopt. Next, hypothesis 2 indicates a positive and significant relationship $(\beta=.22, p<.001)$ between ease of use of MPR application and intention to use. It shows consistent findings with the previous research done by Latiff et. al. (2019) in their study on the use of online TV news on Internet TV in Malaysia. They have identified perceived ease of use is a significant factor that affects students' intention to use Internet TV for their learning experience. Nunkoo and Ramkissoon (2013), also supported that "when the tourist has a comprehensive knowledge of online tourism shopping, they are more focused on utilizing the usefulness of online tourism shopping". Thus, the more users perceived learning MPR application become skillful, the more users adopt to MPR application. Next, hypothesis 3 reported a positive and significant relationship $(\beta=.38, p<.001)$ between the compatibility of MPR application and intention to use. It is consistent with previous studies which discovered that compatibility has been positively affected towards new technologies adoption and integrated with theory such as technology accepted model and planned behaviour (Chen, et. al., 2002). Lastly, hypothesis 4 confirmed that trialability of MPR application give a positive and significant relationship $(\beta=.31, p<.05)$ towards intention to use. Lee et al., (2011) found that trialability is an important predictor influencing people to adopt IPTV. Therefore, the high trialability of MPR application especially on a trial basis influence the users to adopt this application.

As noticed, many researchers explained that Rogers' diffusion and innovation theory is the most appropriate model in determining the adoption of new technology. Rogers (2003) explained that "technology is a design for instrumental action that reduces the uncertainty in the cause-effect relationships involved in achieving the desired outcome" (p. 13). The adoption or rejection of innovation was an important factor in diffusion and adoption 
research and the diffusion of innovations was fundamental to explain human behaviour change.

\section{Conclusion}

Smart Tourism Application (MPR) is believed to be an innovative movement in the tourism viewpoint. It has a modern or trendy pattern where most of the users depend on their smartphones to check on tourism-related information. The current results might be helpful to construct strategies to persuade more consumers to use MPR and hence, it will be an added value to the tourism business and other related organizations such as tourism services like hotels, airline companies, restaurants, food, shopping places, souvenirs, rental-car services and more. Indirectly, it may also create job opportunities for local people and thus, increase their economic sectors. The Malaysian government especially the Minister of Tourism, Arts and Culture Malaysia (MOTAC), may utilize and develop the outcomes of this study in a better way in order to publicize or promote Rembau as the next cultural tourism and travel destination in Malaysia.

This study is very useful to academic research especially in the context of theoretical implications. In the existing study, the researchers employed the new media and technology theory like Diffusion of Innovation in order to examine the effectiveness of smart tourism application. It is proven that Roger's Diffusion of Innovation is among the appropriate model to apply and investigate on users' adoption of new media technology. The findings showed that all of the variables such as relative advantage, trialability, compatibility and ease of use have a positive and significant effect. Moreover, the combination of variables from the Technology Acceptance Model such as ease of use successfully indicated a positive and significant relationship to adoption. As mobile technology is growing rapidly, this research also contributes to practice especially to tourism and hospitalities industries, particularly in developing countries. This research opens new ways to investigate the use of mobile technology in the tourism industry, and the integrative framework may help researchers in developing future research models in stronger and robust ways.

\section{Corresponding Author}

Dzaa Imma Abdul Latiff

Senior Lecturer of Faculty of Communication and Media Studies Universiti Teknologi MARA, Cawangan Negeri Sembilan, 71300 Rembau.

Email: dzaa17@uitm.edu.my

\section{References}

Bae, Y., \& Chang, H. (2012). Adoption of smart TVs: A Bayesian network approach. Industrial Management \& Data Systems, 112(6) 891910.http://dx.doi.org/10.1108/02635571211238509

Chan-Olmsted, S. M., \& Louisa S. H. (2003). Internet business models for broadcasters: How television stations perceive and integrate the internet. Journal of Broadcasting \& Electronic Media. 47(4), 597-617.

Chen, L., Gillenson, M. L., \& Sherrell, D. L. (2002). Enticing online consumers: An extended technology acceptance perspective, Information \& Management, 39(8), 705-19.

Davis, F. D. (1989). Perceived usefulness, perceived ease of use, and user acceptance of information technology. MIS Quarterly. 13, 319-340. 
Davis, F. D., Bagozzi, R. P., \& Warshaw, P. R. (2002). User acceptance of computer technology: A comparison of two theoretical models, Management Science, 35(8), 982-1002.

Ghazali, E. M., Mutum, D. S., Chong, J. H., \& Nguyen, B. (2018). Do consumers want mobile commerce? A closer look at M-shopping and technology adoption in Malaysia. Asia Pacific Journal of Marketing and Logistics, 30(4), 1064-1086. https://doi.org/10.1108/APJML-05- 2017-0093

Gu, D., Khan, S., Khan, I. U., \& Khan, S. U. (2019). Understanding mobile tourism shopping in Pakistan: An integrating framework of Innovation Diffusion Theory and Technology Acceptance Model. Mobile Information Systems, 1490617. 2019, 1-18. https://doi.org/10.1155/2019/1490617

Karakaya, E., Hidalgo, A., \& Nuur, C. (2014). Diffusion of eco-innovations: A review. Renewable and Sustainable Energy Reviews, 33, 392-399. https://doi.org/10.1016/j.rser.2014.01.083

Kefeli, Z. (2020). Pasca-COVID-19: Bersediakah industri pelancongan kesihatan? Bernama. https://bernama.com/bm/tintaminda/ news. php? id=1849344

Latiff, D. I. A., Yasin, M. I., Abdullah, S. N. F., Hassan, A., Noor, M. F. M., Rosdan, N. F. M., (2019). Unique attributes of internet TV in enhancing students' learning experience. Journal of Forum Komunikasi, 14(2), 1-19.

Latiff, D. I. A., Yasin, M. I., Ramli, N., Ridzuan, A. R., A., Mohideen, S. R., \& Ghani, S. N. F. F. A. (2017). Understanding innovation diffusion attributes towards internet tv adoption in enhancing students learning experience. Journal of Academia, 5(1), 178-186.

Lee, Y.-H., Hsieh, Y.-C., \& Hsu, C.-N. (2011). Adding innovation diffusion theory to the technology acceptance model: Supporting employees' intentions to use e-learning systems. Educational Technology \& Society, 14(4), 124-137.

Min, S., So, K. K. F., \& Miyoung, J. (2019) Consumer adoption of the uber mobile application: Insights from diffusion of innovation theory and technology acceptance model, Journal of Travel \& Tourism Marketing, 36(7), 770-783, https://doi.org/10.1080/10548408.2018.1507866

Moore, G. C., \& Benbasat, I. (1991). Development of an instrument to measure the perceptions of adopting an information technology innovation, Information Systems Research, 2(3), 192-222.

Nunkoo, R., \& Ramkissoon, H. (2013). Travelers' E-purchase intent of tourism products and services. Journal of Hospitality Marketing \& Management, 22(5), 505-529

Polites, G. L., \& Karahanna, E. (2012). Shackled to the status quo: The inhibiting effects of incumbent system habit, switching costs, and inertia on new system acceptance. MIS Quarterly, 36(1), 21- 42.

Rogers, E. M. (2003). Diffusion of innovation, 5th ed. The Free Press.

Rogers, E. M. (1983). Diffusion of Innovations, 3rd ed. The Free Press

Scott. S., \& McGuire, J. (2017). Using diffusion of innovation theory to promote universally designed college instruction. International Journal of Teaching and Learning in Higher Education. 29(1), 119-128.

Talukder, M. (2014). Managing innovation adoption: From innovation to implementation. Surrey: Gower Publishing. https://doi.org/10.1155/2019/1490617

Venkatesh, V., Morris, M., Davis, G. B., \& Davis, F. D. (2003). User acceptance of information technology: Toward a unified view, MIS Quarterly, 27(3), 425-478 
Wong, C. H., Tan, G. W. H., Ooi, K. B., \& Lin, B. (2015). Mobile shopping: The next frontier of the shopping industry? An emerging market perspective. International Journal of Mobile Communications, 13(1), 92-112.

Wu, J. H., \& Wang, S. C. (2005). What drives mobile commerce? An empirical evaluation of the revised technology acceptance model. Information management, 42(5), 719-729. 